\title{
PENINGKATAN HASIL BELAJAR SISWA MELALUI TEKNIK BERMAIN PERAN PADA MATA PELAJARAN IPS POKOK BAHASAN PROKLAMASI KEMERDEKAAN
}

\author{
Rossi Iskandar \\ PGMI UIN Sunan Gunung Djati Bandung \\ Jalan A.H. Nasution No. 105, Cipadung, Cibiru, Kota Bandung, Jawa Barat 40614 \\ Rossiiskandar92@gmail.com
}

\begin{abstract}
Research aims to know role playing's tech implement on social science learning. Method that is utilized in this research is observational action braze. Its data collecting tech is by use of activity observation sheet student and teacher and sheet essay. Base analisis observational already been done that tech implement plays performed role with every consideration. Activity learns on i. cycle is $81.8 \%$ and on cycle II. by derived $90.9 \%$ meanwhile on 100 performed III. cycle $\%$ of 22 aspect those are proposed.
\end{abstract}

Keyword: Social science, learning outcome, role playing, independence proclamation

\begin{abstract}
Abstrak: Penelitian bertujuan untuk mengetahui penerapan teknik bermain peran pada pembelajaran ilmu pengetahuan sosial. Metode yang digunakan dalam penelitian ini adalah penelitian tindakan kelas. Teknik pengumpulan datanya adalah dengan menggunakan lembar observasi aktivitas siswa dan guru serta lembar tes. Berdasarkan analisis penelitian yang telah dilakukan bahwa penerapan teknik bermain peran terlaksana dengan baik. Aktivitas guru pada siklus I adalah $81.8 \%$ dan pada siklus II dengan perolehan $90.9 \%$ sedangkan pada siklus III terlaksana $100 \%$ dari 22 aspek yang diajukan.
\end{abstract}

Keyword: Ilmu pengetahuan sosial, hasil belajar, bermain peran, proklamasi kemerdekaan

Proses pendidikan di sekolah akan berjalan dengan baik dan bermakna bila di dukung oleh sarana dan prasarana yang lengkap dan baik. Sarana dan prasarana adalah segala sesuatu yang dipergunakan oleh seorang guru/pendidik dalam usaha untuk mencapai tujuan pendidikan baik pendidikan umum maupun agama. Pendidikan adalah suatu kunci keberhasilan yang perlu dimiliki oleh setiap manusia agar dapat menyesuaikan dengan nilai-nilai dan norma-norma yang ada pada masa sekarang dan yang akan datang. Dengan demikian pendidikan adalah fondasi dari segala-galanya.

Menghadapi era-globalisasi sekarang ini perlu adanya pembaharuanpembaharuan sistem pendidikan yang dapat menunjang keberhasilan pendidikan khususnya di Indonesia. Dalam hal ini, lembaga pendidikan memiliki posisi strategis untuk meningkatkan peserta didik dengan di dukung oleh guru yang profesional, serta sarana dan prasarana yang baik. Proses pembelajaran dapat dicapai semaksimal mungkin, sebagaimana 
di kemukakan di dalam BAB II pasal 3 Undang-undang Nomor 20 tahun 2003 tentang Sistem Pendidikan Nasional, yaitu bahwa :

"Pendidikan Nasional berfungsi mengembangkan kemampuan dan membentuk watak serta peradaban bangsa yang bermartabat dalam rangka mencerdaskan kehidupan bangsa, bertujuan untuk berkembangnya potensi peserta didik agar menjadi manusia yang beriman dan bertakwa kepada Tuhan Yang Maha Esa, berakhlak mulia, sehat, berilmu, cakap, kreatif, mandiri, dan menjadi warga negara yang demokratis serta bertanggung jawab".

Berdasarkan Undang-undang No. 20 tahun 2003 tersebut, maka lembaga pendidikan mempunyai fungsi pengembangan kemampuan peserta didik baik secara intelektual, emosional, spiritual, dan juga skill (keterampilan) tak terkecuali dengan pendidikan IPS, pendidikan IPS haruslah melatih intelektual, emosional dan skill untuk mempersiapkan generasi muda, baik kejenjang yang lebih tinggi, maupun terjun aktif dalam kehidupan masyarakat. Mengingat pentingnya pendidikan IPS, maka guru IPS mempunyai tugas yang cukup berat, tidak hanya melatih peserta didik untuk memahami, mengerti dan mampu berbuat sesuatu yang diharapkan oleh pendidikan IPS.
Pembelajaran IPS sekarang ini harus bisa mengubah dari situasi"guru mengajar" kepada situasi "peserta didik belajar", dari pengalaman guru kepada pengalaman peserta didik, dari dunia guru kepada dunia peserta didik. Mengorganisir sekolah bukan untuk kita mengajar tetapi untuk peserta didik belajar. Guru yang modern ialah orang yang mengayom proses belajar peserta didik. Ia menempatan peserta didik kepada pusat kegiatan belajar, membantu dan mendorong peserta didik untuk belajar, bagaimana menyusun pertanyaan, bagaimana membicarakan dan menemukan jawaban-jawaban persoalan. Guru IPS sebagai fasilitator, motivator, counselor dalam kelas. Guru IPS sudah saatnya mencari metode belajar yang tepat, agar suasana belajar yang menyenangkan dapat terlihat dalam kehidupan sehari-hari.

Berdasarkan wawancara penulis dengan guru IPS yang ada di MI Negeri Maparah Kabupaten Ciamis, hubunganya dengan kegiatan belajar mengajar IPS kebanyakan metode yang digunakan adalah metode ceramah yang dilakukan pada umumnya, walaupun sesekali di gunakan metode yang lain seperti metode diskusi, metode discovery, metode inquiry dan pemberian tugas sehingga dengan metode seperti itu menyebabkan peserta 
didik merasa jenuh dan menyebabkan hasil belajar peserta didik menurun.

Dalam upaya meningkatkan hasil belajar kognitif peserta didik pada mata pelajaran IPS, maka diperlukan strategi dan metode pembelajaran yang tepat untuk meningkatkan hasil belajar peserta didik. Menurut Tiana, (2008:52) metode sebagai bagian dalam proses belajar mengajar di akui keberadaanya. Tidak ada satupun kegiatan belajar mengajar luput dari peran metode. Dengan kata lain metode adalah cara yang digunakan guru dalam menyampaikan bahan pelajaran agar tujuan atau kompetensi dasar dapat tercapai. Salah satu metode pembelajaran yang tepat untuk meningkatkan hasil belajar kognitif peserta didik adalah dengan menggunakan metode pembelajaran bermain peran (Role Playing) metode ini di pelopori oleh George Shafetel, (Uno 2008; 25)

Berdasarkan alasan tersebut, ditawarkan sebuah metode pembelajaran IPS dengan metode kooperatif tipe role playing atau bermain peran yang merupakan suatu cara penguasaan bahanbahan pelajaran melalui pengembangan imajinasi dan penghayatan peserta didik. Pengembangan imajinasi dan penghayatan itu dilakukan peserta didik dengan memerankannya sebagai tokoh hidup atau benda mati.

Bermain peran adalah metode yang sangat efektif digunakan untuk mensimulasikan keadaan nyata, bermain peran adalah salah satu bentuk pembelajaran, dimana peserta didik ikut terlibat aktif memainkan peran-peran tertentu. Bermain pada anak merupakan salah satu sarana untuk belajar. Melalui kegiatan bermain yang menyenangkan, anak berusaha untuk menyelidiki dan mendapatkan pengalaman yang kaya, baik pengalaman dengan dirinya sendiri, orang lain maupun dengan lingkungan di sekitarnya.

Melalui metode bermain peran pesera didik diajak untuk belajar memecahkan masalah pribadi, dengan bantuan kelompok sosial yang anggotanya teman-temannya sendiri. Berdasarkan penelitian Poorman (2002), siswa yang diwawancarai mengatakan bahwa dengan strategi bermain peran yang dilaksanakan oleh guru, membuat mereka ingin terlibat aktif melakukan sesuatu dalam pembelajaran. Hal ini senada sebagaimana yang diteliti Fogg (2001) bahwa pembelajaran yang menggunakan strategi bermain peran meningkatkan keaktifan siswa dalam kegiatan belajar. 
Hasil Belajar IPS melalui Teknik bermain Peran

Rossi Iskandar

Metode bermain peran adalah metode yang sangat efektif digunakan untuk mensimulasikan keadaan nyata. Dalam metode ini disusun sebuah skenario pembelajaran berdasarkan pada prosedur operasional atau kegiatan yang akan diajarkan. Bermain peran dapat membuktikan diri sebagai suatu media pendidikan yang ampuh, dimana saja terdapat peran-peran yang dapat di definisikan dengan jelas, yang memiliki interaksi untuk di eksplorasi dalam keadaan yang bersifat simulasi (Hamzah 2008: 25).

Bermain peran merupakan suatu proses memberikan contoh hidup dari perilaku manusia yang berfungsi sebagai kendaraan bagi siswa untuk mengeksplorasi mereka perasaan; (2) memperoleh wawasan sikap mereka, nilainilai, dan persepsi; (3) mengembangkan mereka pemecahan masalah keterampilan dan sikap; dan (4) mengeksplorasi materi pelajaran dengan berbagai cara (Joyce dan Weil, 2009).

Metode ini banyak melibatkan peserta didik dan membuat peserta didik senang belajar serta metode ini mempunyai nilai tambah, yaitu dapat menjamin partisipasi seluruh peserta didik dan memberi kesempatan yang sama untuk menunjukkan kemampuannya dalam bekerjasama hingga berhasil, dan permainan merupakan pengalaman yang menyenangkan bagi peserta didik. Menurut J. Piaget yang dikutip oleh Hendy (2010:34) bahwa dalam aplikasi praktisnya sangat mementingkan keterlibatan peserta didik secara aktif dalam proses belajar, sehingga hanya dengan mengaktifkan peserta didik maka proses asimilasi /akomodasi pengetahuan dan pengalaman dapat terjadi dengan baik. Oleh karena itu, guru diharapkan dapat membangkitkan perhatian peserta didik hingga terjadilah komunikasi timbal balik, sehingga metode kooperatif dengan teknik bermain peran ini cocok dilaksanakan pada suatu pembelajaran di madrasah.

Bermain peran sebagai instruksional menurut Gunter, dkk (2002) adalah sebagai strategi mengambil keuntungan dari praktek-praktek pembelajaran dalam menghubungkan pengalaman baru untuk pengetahuan sebelumnya dan pengalaman, dan melakukannya di perusahaan orang lain.

Menurut Mulyasa

(2004:141) terdapat empat asumsi yang mendasari pembelajaran bermain peran untuk mengembangkan perilaku dan nilai-nilai social, yang kedudukannya sejajar dengan model-model mengajar lainnya. Keempat asumsi tersebut sebagai berikut: 
Secara implisit bermain peran mendukung sustau situasi belajar berdasarkan pengalaman dengan menitikberatkan isi pelajaran pada situasi "di sini pada saat ini". Model ini percaya bahwa sekelompok peserta didik dimungkinkan untuk menciptakan analogy mengenai situasi kehidupan nyata. Terhadap analogy yang diwujudkan dalam bermain peran, para peserta didik dapat menampilkan respons emosional sambil belajar dari respons orang lain.

Kedua, bermain peran memungkinkan para peserta didik untuk mengungkapkan perasaannya yang tidak dapat dikenal tanpa bercermin pada orang lain. Mengungkapkan perasaan untuk mengurangi beban emosional merupakan tujuan utama dari psikodrama (jenis bermain peran yang lebih menekankan pada penyembuhan). Namun demikian, terdapat perbedaan penekanan antara bermain peran dalam konteks pembelajaran dengan psikodrama. Bermain peran dalam konteks pembelajaran memandang bahwa diskusi setelah pemeranan dan pemeranan itu sendiri merupakan kegiatan utama dan integral dari pembelajaran; sedangkan dalam psikodrama, pemeranan dan keterlibatan emosional pengamat itulah yang paling utama. Perbedaan lainnya, dalam psikodrama bobot emosional lebih ditonjolkan daripada bobot intelektual, sedangkan pada bermain peran peran keduanya memegang peranan yang sangat penting dalam pembelajaran.

Ketiga, model bermain peran berasumsi bahwa emosi dan ide-ide dapat diangkat ke taraf sadar untuk kemudian ditingkatkan melalui proses kelompok. Pemecahan tidak selalu datang dari orang tertentu, tetapi bisa saja muncul dari reaksi pengamat terhadap masalah yang sedang diperankan. Denagn demikian, para peserta didik dapat belajar dari pengalaman orang lain tentang cara memecahkan masalah yang pada gilirannya dapat dimanfaatkan untuk mengembangkan dirinya secara optimal. Dengan demikian, para peserta didik dapat belajar dari pengalaman orang lain tentang cara memecahkan masalah yang pada gilirannya dapat dimanfaatkan untuk mengembangkan dirinya secara optimal. Oleh sebab itu, model mengajar ini berusaha mengurangi peran guru yang teralu mendominasi pembelajaran dalam pendekatan tradisional. Model bermain peran mendorong peserta didik untuk turut aktif dalam pemecahan masalah sambil menyimak secara seksama bagaimana orang lain berbicara mengenai masalah yang sedang dihadapi. 
Ke empat, model bermain peran berasumsi bahwa proses psikologis yang tersembunyi, berupa sikap, nilai, perasaan dan system keyakinan, dapat diangkat ke taraf sadar melalui kombinasi pemeranan secara spontan. Dengan demikian, para peserta didik dapat menguji sikap dan nilainya yang sesuai dengan orang lain, apakah sikap dan nilai yang dimilikinya perlu dipertahankan atau diubah. Tanpa bantuan orang lain, para peserta didik sulit untuk menilai sikap dan nilai yang dimilikinya.

Permasalahan diatas menjadi perhatian bagi peneliti untuk mengadakan penelitian tindakan kelas terhadap pengaruh metode bermain peran (Role Playing) dalam meningkatkan hasil belajar.

\section{METODE}

Metode penelitian yang digunakan dalam penelitian ini adalah metode penelitian kelas (classroom research action). Metode ini mengkaji dan merefleksi suatu model pembelajaran dengan tujuan untuk meningkatkan proses pembelajaran di kelas.

Langkah-langkah yang akan dilakukan dalam penelitian ini berbentuk siklus. Setiap siklus Menurut Sulipan yang dikutip oleh Nizar Alam (2008: 52) tahapan dalam penelitian kelas terdiri dari empat tahapan, yaitu (1) perencanaan tindakan, (2) pelaksanaan tindakan, (3) pengamatan terhadap tindakan dan (4) refleksi terhadap tindakan. Pada pelaksanaannya, keempat komponen kegiatan pokok itu berlangsung secara terus menerus.

Subjek dalam penelitian ini adalah satu kelas yaitu kelas V MIN Maparah dengan jumlah peserta didik sebanyak 25 orang.

\section{HASIL}

\section{Observasi Guru dan Siswa}

Hasil observasi yang dilakukan kinerja guru dan aktivitas siswa selama berlangsungnya pembelajaran proklamasi kemerdekaan dengan menerapkan teknik bermain peran diperoleh data guru melaksanakan 18 aspek atau 81,8\% dari 22 aspek yang ditetapkan, sedangkan nilai tertinggi aktivitas siswa dengan menggunakan teknik bermain peran adalah 85 dan nilai terendahnya yaitu 40 . rata-rata dari keseluruhan aktivitas siswa adalah $56 \%$ berada pada katagor kurang.

Selama proses pembelajaran proklamasi kemerdekaan pada siklus II ini, guru melaksanakan 20 aspek atau $90.9 \%$ dari 22 aspek yang ditetapkan dan pada siklus I ada 18 aspek atau $81.8 \%$, hal ini terlihat ada peningkatan pada kinerja guru. 
nilai tertinggi aktivitas siswa dengan menggunakan teknik bermain peran adalah 85 dan nilai terendah yaitu 50 Sedangkan nilai rata-rata dari keseluruhan aktivitas siswa adalah $65.6 \%$ berada pada kategori sedang.

Pada siklus III ini. Guru sudah melaksanakan semua aspek yang ditetapkan, yakni 22 aspek atau $100 \%$. Sedangkan aktivitas siswa mengalami peningkatan dari siklus sebelumnya. Hal tersebut ditunjukan oleh peningkatan skor jumlah aktivitas siswa dari seluruh siklus yaitu pada siklus I $56 \%$, pada siklus II $65.6 \%$ dan pada siklus III meningkat menjadi $78.8 \%$.

Dari hasil tes teridentifikasi bahwa nilai rata rata peserta didik adalah 61.2 dengan nilai terbesar 70 dan nilai terkecil 50 hasil ini sangat jauh sekali dari kriteria ketuntasan minimal mata pelajaran Ilmu Pengetahuan Sosial (IPS) pada materi proklamasi kemerdekaan, yaitu 70 maka sangat perlu diberikan tindakan kelas untuk mata pelajaran ilmu pengetahuan sosial (IPS) pada materi proklamasi kemerdekaan .

Berdasarkan perhitungan ketuntasan individual dan klasikal pada siklus II dapat disimpulkan bahwa perolehan rata-rata kelas sebesar 68 sehingga termasuk ke dalam kategori sedang, sedangkan untuk ketuntasan klasikal sebesar $68 \%$ dari jumlah siswa yang berjumlah 25 peserta didik dan dapat dikatakan masih dalam kategori sedang.

Berdasarkan hasil tes pada siklus III maka diperoleh hasil rata rata nilai dari siklus III adalah 79.2 dengan nilai tertinggi 96 dan nilai terendah 70. Hasil ini menunjukan bahwasanya setelah dilakukan tindakan III adanya perubahan pada hasil belajar siswa. Beberapa siswa yang pada siklus 1 dan II yang nilainya masih dibawah atau sama dengan nilai kriteria ketuntasan minimal, pada siklus III peserta didik tersebut mampu mencapai nilai kriteria ketuntasan minimal untuk mata pelajaran Ilmu Pengetahuan Sosial (IPS) pada materi Proklamasi Kemerdekaan ini yaitu 70 .

\section{PEMBAHASAN}

Berdasarkan hasil observasi guru dan data aktivitas siswa maka terdapat hal-hal yang harus diperbaiki pada siklus berikutnya.

Pada pelaksanaan pembelajaran siklus I temuan yang dianalisis dalam proses maupun peningkatan aktivitas belajar siswa antara lain sebagai berikut:

1) Pada waktu siswa dibagi kelompok, situasi kelas menjadi gaduh, karena 
siswa mencari tempat duduk untuk anggota kelompoknya.

2) Selama kegiatan diskusi kelompok mengenai naskah dialog, ada bebeerapa siswa pada tiap kelompok yang tidak ikut berperan yaitu sebagian siswa acuh dengan pemberian tugas dari guru.

Dari analisis siklus I di atas maka ada beberapa hal yang harus diperhatikan untuk perbaikan pada siklus berikutnya di antaranya adalah:

1) Pada waktu siswa ribut di dalam kelas karena membentuk kelompok, maka untuk memperbaiki hal tersebut perbaikan pada siklus II bisa dilakukan dengan cara guru sebelumnya menentukan tempat duduk siswa untuk masing-masing kelompok.

2) Ketika diskusi kelompok ada sebagian siswa yang tidak berpartisipasi, untuk itu pada siklus II guru harus membimbing siswa pada setiap kelompok.

Hasil observasi peningkatan aktivitas siswa maka diperoleh beberapa data pelaksanaan tindakan dalam proses pembelajaran yang dianalisis untuk perbaikan pada pelaksanaan pembelajaran siklus berikutnya.
Dari analisis pelaksanaan tindakan siklus II di atas maka ada beberapa hal yang harus diperhatikan untuk perbaikan pada siklus III antara lain sebagai berikut:

1) Ketika siswa kurang leluasa untuk menunjukkan ide-idenya pada kegiatan diskusi dan tidak berani dalam mementaskan drama, maka untuk mengatasi hal tersebut sebagai perbaikan pada siklus III dilakukan dengan masing-masing siswa setiap kelompok ditugasi untuk mengemukakan idenya secara bergiliran serta memberikan penghargaan terhadap siswa atau kelompok yang berani mementaskan di depan kelas supaya siswa lain terpacu berani untuk mementaskannya di depan kelas.

2) Ketika guru kurang memberikan penjelasan tentang materi, maka terlebih dahulu guru berdiskusi dengan peneliti mengenai cara penyampaian yang diberikan.

Berdasarkan hasil analisis dan refleksi proses pembelajaran siklus III, temuan yang diperoleh dapat disimpulkan sebagai berikut:

1) Siswa dalam setiap melakukan kegiatan kelompok sudah mampu menunjukkan tugas yang ada dalam 
kelompok melaluii pembelajaran dengan menggunakan teknik bermain peran

2) Siswa sudah menunjukkan sikap tanggung jawab dan kerja sama selama mengikuti kegiatan belajar, hal ini ditunjukkan oleh kekompakan siswa dalam melakukan pelatihan bermain drama dengan materi pembelajaran proklamasi kemerdekaan dan mementaskannya di depan kelas setiap kelompok, oleh karena itu kemampuan dan aktivitas belajar siswa meningkat.

3) Selama kegiatan pembelajaran guru telah melakukan kegiatan membimbing siswa dan memberikan arahan kepada siswa tentang langkah-langkah dalam pembelajaran IPS tentang proklamasi kemerdekaan dengan menggunakan teknik bermain peran.

Salah satu faktor yang sangat mendukung keberhasilan guru dalam melaksanakan proses pembelajaran adalah kemampuan guru dalam menguasai dan menerapkan metode pembelajaran, ketidaktepatan dalam memilih metode dapat berakibat tidak tercapainya tujuan pembelajaran. Agar peserta didik lebih terdorong dalam belajar, maka skenario pembelajaran harus dibuat sedemikian hingga mampu membangkitkan rangsangan hingga mampu menumbuhkan minat belajar peserta ddik. Salah satu cara untuk minigkatkan hasil belajar peserta didik dalam mempelajari materi proklamasi kemerdekaan pada mata pelajaran Ilmu Pengetahuan Sosial (IPS) adalah dengan menggunakan teknik bermain peran. Melalui kegiatan ini peserta didik lebih aktif dalam melakukan penghayatan suatu tokoh sehingga keterampilan, imajinasi dan karakter peserta didik bisa ditunjukan dalam kehidupan nyata atau kehidupan sosial.

\section{SIMPULAN}

Pelaksanaan penerapan teknik bermain peran pada mata pelajaran IPS tentang proklamasi kemerdekaan pada setiap siklus terlaksana dengan baik. Hal ini terlihat dari meningkatnya hasil rata-rata aktivitas guru dan siswa pada setiap siklus. Aktivitas guru pada siklus I adalah $81.8 \%$ hasilnya meningkat pada siklus II dengan perolehan $90.9 \%$ dan siklus III $100 \%$ terlaksana . Sedangkan aktivitas siswa pada siklus I hanya $56 \%$ sedangkan pada siklus II meningkat menjadi $65.6 \%$ dan pada siklus III meningkat menjadi $78.8 \%$. 
Peningkatan hasil belajar peserta didik di kelas V MIN Maparah yang memperoleh belajar dengan menggunakan teknik bermain peran. Peningkatan hasil belajar peserta didik dalam pembelajaran IPS materi proklamasi kemerdekaan melalui penerapan teknik pembelajaran bermain peransetiap siklus meningkat. Terlihat adanya peningkatan pada siklus I nilai rata ratanya 61.2 atau 32\%dengan nilai tertinggi 70 dan nilai terendah 50 Pada siklus II rata ratanya 68atau $68 \%$ dengan nilai tertinggi 80 dan nilai terendah 60. Pada siklus III rata ratanya 79.2 atau 96\% dengan nilai tertinggi 90 dan nilai terendah 70. Dari data tersebut dapat dilihat peningkatan hasil belajar peserta didik yang signifikan.

\section{DAFTAR RUJUKAN}

Juliansyah,Tiana, (2010). Kiat Kiat Terbaik Untuk Guru.Bandung: PT Setia Purna

Uno, B Hamzah, (2012). Model Pembelajaran. Jakarta: Bumi aksara

Prihatin, Eka, (2008). Guru sebagai fasilitator. Bandung. PT Karsa Mandiri

Hermawan, Hendy, (2010). Teori Belajar dan Motivasi. Bandung: CV.Citra Praya

Mulyasa, E, (2004). Implementasi Kurikulum 2004: Panduan Pembelajaran KBK. Bandung: Remaja Rosdakarya.
Joyce, B., Weil, M., and Calhoun, E., (2009). Models of teaching (8th ed.). Boston, MA: Allyn \& Bacon.

Gunter, M. A., Estes, T. H., and Schwab, J. H., (2002). Instruction: A models approach (4th ed.). Boston, MA: Allyn \& Bacon.

Nizar, dkk. (2008). Classroom Action Research. Rahayasa.

Fogg, P. (2001). A history professor engages students by giving them a role in the action. Chronicle of Higher Education.

Poorman, P. B. (2002). Biography and role-playing:fostering empathy in abnormal psychology. Teaching of Psychology. 